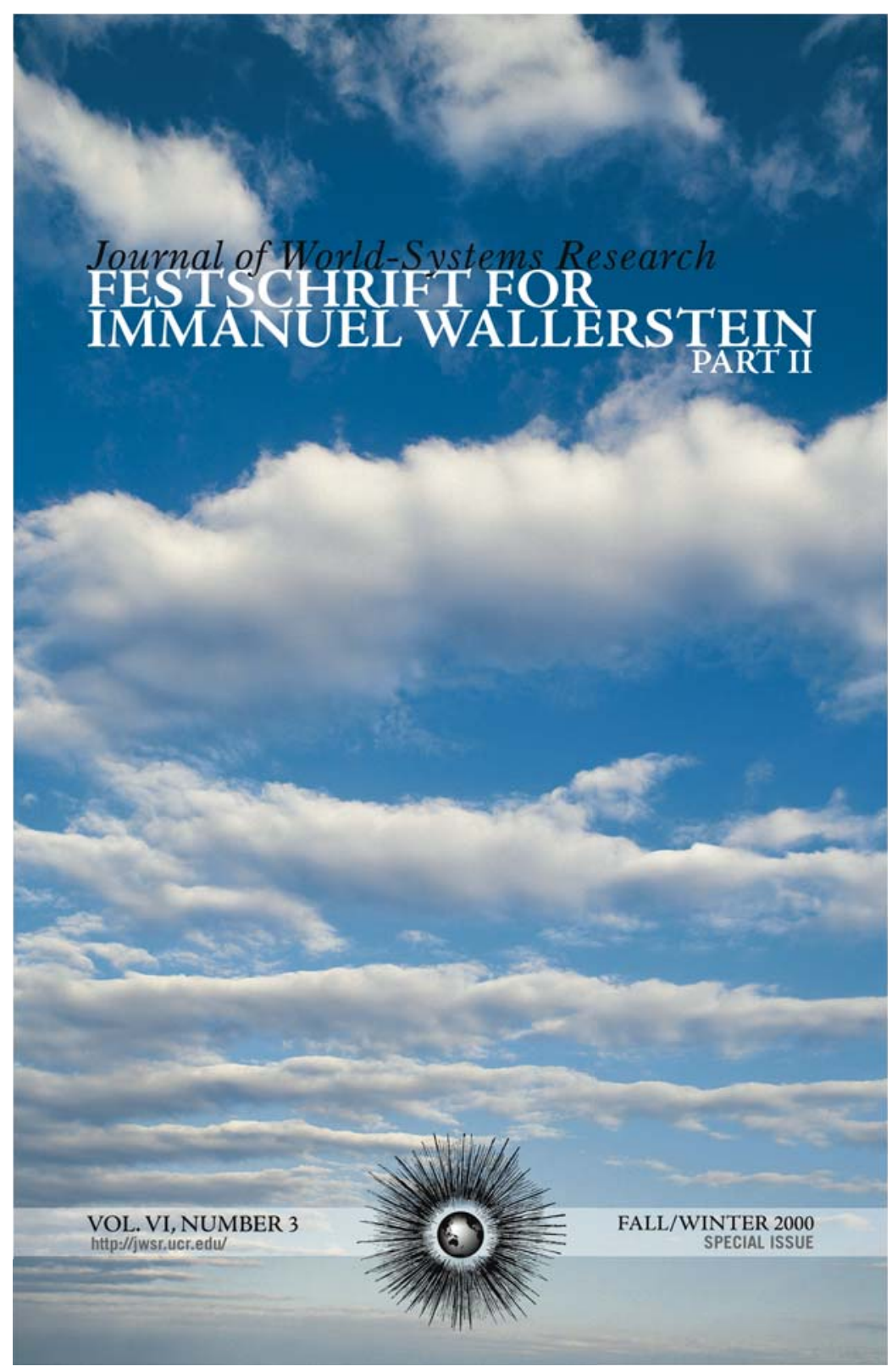

"Globalization" and the "Permanent" Process of "Primitive Accumulation": The Example of the MAI, the Multilateral Agreement on Investment ${ }^{*}$

Claudia von Werlhof

\title{
INTRODUCTION
}

$A^{t}$ the 1985 annual meeting of the American Sociological Association A in Washington, I had, at the invitation of Immanuel Wallerstein, the opportunity to present my theses on the subject "Why Peasants and Housewives do not Disappear in the Capitalist World System" (Werlhof 1985). Some years later, in an article with the same title, I dealt with the basic thesis of the presentation at ASA for the entire process of accumulation, namely the permanent relevance of processes of so-called "primitive accumulation" (1991). I am glad to come back to the subject in my contribution to this commemorative volume, though I shall deal with it in a new context: the so-called globalization debate. Thus a process is coming full circle: It began towards the end of the seventies, when we met Immanuel in Germany, continued when we organized a conference at the University of Bielefeld with him and a team from Binghamton, and ended when we finally published a few things together (Smith, Wallerstein, Evers 1984; Review 1980 and 1983). In 1985 , when my habilitation was to be published, Immanuel wrote a preface to it, in which he pointed out that it was necessary to understand

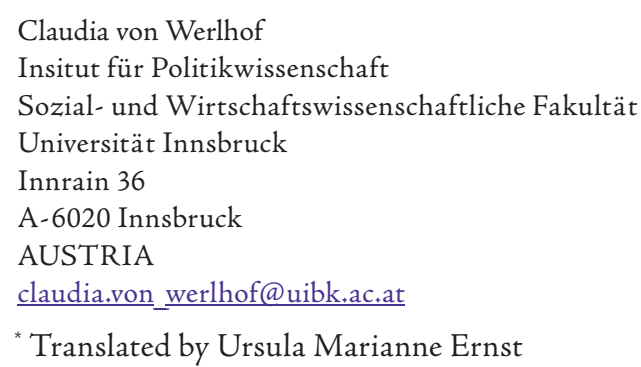

Translated by Ursula Marianne Ernst

JOURNAL OF WORLD-SYSTEMS RESEARCH, VI, 3, FALL/WINTER 2000, 728-747 Special Issue: Festchrift for Immanuel Wallerstein - Part II

http://jwsr.ucr.edu

ISSN IO76-I56x

(C) 2000 Claudia von Werlhof 
that the world was seen "upside down," and that it was, therefore, our task to make this fact with all its consequences as clear as possible (Wallerstein 1985). Today, fourteen years later, the necessity of analyzing these "perversions" has become even more indispensable, since the processes within the "capitalist world system" are constantly gaining speed, moving towards a point which is diametrically opposed to all predictions of a positive path to increasing prosperity and democracy, and less violence in our world society. Therefore, I want to go back to my approach to the "permanence" of "primitive accumulation" and its global dimensions and try to analyze today's socalled process of "globalization," especially the "Summit of Globalization" (Kommittee Widerstand gegen das MAI 1998), the "Multilateral Agreement on Investment," the MAI (OECD 1997, 1998).

\section{THE POLITICAL ECONOMY OF "GLOBALIZATION": THE MAI}

The MAI is a draft text of an agreement which, since 1995, has been negotiated in Paris by the 29 largest industrial states organized in the OECD (Organization of Economic Co-operation and Development), entirely outside of the public gaze. In 1997, the draft was leaked to the public by deliberate indiscretion and it reached the world public through the analyses of Tony Clarke from Canada and Martin Khor from Malaysia (Clarke 1997, Clarke and Barlow 1997, 1998; Khor). Since then international resistance to signing the draft agreement, which had to be postponed several times, has been growing constantly. Thousands of environmental, women's, third world, church and other "civil society" groups (Korten 1998) in OECD countries, as well as an increasing number of groups of the South, are engaged in opposition to the MAI. The last round of negotiations in Paris, in October 1998, was paralysed by the French Prime Minister, Jospin, who declared his country's secession from the negotiations following his reading of a report on the potential consequences of the application of the MAI (TAZ 15.10.1998). At present, there is speculation as to whether the MAI is finished on account of this last round of negotiations, whether it should be put back onto the level of the WTO (World Trade Organization) where it originally came from, or if it will come up again in different international contexts such as the IMF (International Monetary Fund), the so-called "Transatlantic Market Place," or other institutions that would be established.
In the meantime, there is one thing the MAI has made clear: the interests behind it still exist and they continue to push toward its realization. The effort to formulate an "agreement on investment protection"- which has the character of nothing less than a new political world constitution-could hardly be explained otherwise. For the MAI does not, as it seems, regulate investment activities, instead it regulates politics. The MAI is a "License to Loot" (Mies and Werlhof 1998) for big business at the expense of the rest of humankind and nature. It is the final consequence of neo-liberal globalization, and the permanent codification of the reversal of everything else that has so far been claimed to be the aim of economy and politics, such as democracy, prosperity, freedom, self-realization, human rights and a bright future for everybody. Without any explanation, let alone any apology, the MAI shatters these illusions.

\section{THE HISTORICAL BACKGROUND}

The MAI-according to my understanding-underpins and formalizes the new political economy required by the main actors of the world economy under conditions of monopoly and a new "industrial revolution." In the decades after the second World War, and particularly since the seventies, new conditions of production and politics favorable for capital have emerged, conditions which stand on the brink of becoming a new global norm or standard. These new conditions include certain kinds of use and organic composition of capital, as well as the orientation towards a certain profit level which, viewed historically, is very high today because it has adjusted to something like an "average" speculation-profit. To maintain this level, an adequate global political constitution must be established, producing the "necessary" prerequisites for the realization of such a phase of the world-economy, including adequate sanctions (that is, the use of violence against "deviant" parties). As a result, the MAI has been negotiated by the nation-states' governments, which seems paradoxical because the MAI is doing away with large parts of national sovereignty. It is these very governments that-from the beginning of the contemporary world-economy, the "Capitalist World-System"- have been concerned chiefly with producing and enforcing sovereignty. The nation-state and international division of labor have from the very start worked together, such that the nation-state can be analyzed only from an international and colonial perspective (Waller- 
stein 1974a, 1980, 1989; Mies 1986; Mies and Shiva 1993). The same is true today: it has always been the "world-system" and not the nation-state, which forms the analytic entity that informs us about our present situation (Wallerstein 1974b). Since world economic conditions have changed in the meantime, the nation-state constitution should or must be adjusted to the new development.

So much for the political side of political economy; let us now look at its economic side.

Seen historically, changes in the world political economy are nothing new. The economy of the modern period-capitalism-began as a worldwide process, namely as colonization by Europe and within Europe ("external" and "internal" colonization). The process was described by Karl Marx (1974) as a process of "separating the producers from their means of production," a process of so-called "original" or "primitive" accumulation. This process was considered to be the historical prerequisite for the subsequent process of "capital accumulation proper." Rosa Luxemburg (1971) applied this analysis to the entire world. For not only in Europe, but also in the colonies peasants and craftsmen, the producers in those days, were "separated" from their opportunities, means and traditions of production which, if not destroyed outright in the course of this process, had to be handed over to the new masters: the colonial rulers or land owners.

Feminist research has extended this analysis, bringing into this process women, who, by witch hunts in Europe and by colonization outside Europe, were the first to be separated from their work and production means, their culture, their knowledge, and their skills, and from control over their own labor and even their bodies because of their reproductive capacities. Thus, in a very special way, women, too, lost control over their immediate living conditions and even themselves as living beings, having been transformed into "housewives." Since this process is still taking place today and, in order to be effective, "must" be forced anew upon every new generation, we have coined the term worldwide "permanent" primitive accumulation (Werlhof 1978; Mies 1986 is calling it the "ongoing" process of primitive accumulation). The extension of the term helps to recognize the extent to which modern political economy, up to the present, builds upon the producers', men's, and even more so women's, permanent worldwide expropriation and deprivation of power. They have not only historically been robbed by "original accumulation," they are still robbed, again and again. The process of capital accumulation still depends on "primitive accumulation," which, therefore, cannot only - as Marx did-be understood as earlier or preceding accumulation, but must always and simultaneously be seen as a necessary part of ongoing accumulation. Thus, original accumulation is not only chronologically but also logically an integral part of accumulation and possesses a clearly capitalist and not a "pre-capitalist" or "non-capitalist"(A.G. Frank) character. In other words, a component of capitalist accumulation is always "original accumulation."

For the first time in history since the beginning of processes of original accumulation, the immediate producers are not fundamentally producing to mutually provide for themselves and for each other locally or regionally-a form of economy based on so-called "subsistence production" - but are used (exploited) as raw material (producers) for the entire process of capital utilization and accumulation. This does not occur evenly and uniformly over the entire world; rather, there is an inherent tendency toward homogenization and uniformity which has become the principle of economic and political behavior. It is in this way that the political economy of the "capitalist world system" has come about: Africa produced the mass of the labor force that as slaves - the "raw material" of labor-produced the raw material of colonial commodities in America, especially in the form of agricultural and mining products which, in turn, served as material for European industrialization on the basis of proletarian wage labor. The latter includes the mostforgotten "inner" colony of "housewives" (Bennholdt-Thomsen, Mies and Werlhof 1988), who during their lifetimes had-according to the "African model"- to work without wages for the "(re-)production" of the next generation of labor.

After original accumulation had robbed many people of their culture, and crucially of their means of production, the process continued in attempting to separate them from their labor and even their bodies. Those who after the first phase of original accumulation were at least paid for their labor often forget that such payment is based upon the twofold expropriation of those who, at the lower end of the accumulation process, bear the full brunt of "permanent" primitive accumulation. This is the reason why trade unions have never tried to organize "precarious" employees, such as foreigners and women, to say nothing of housewives. For this same reason, leftist theory 
has seen only wage labor as central to accumulation and value production. Similarly, leftist politics has only focused on "free wage laborers" - the industrial proletariat-particularly those in the core, according to the (false) notion that everything else is part of the past and belongs to the historical phase of original accumulation, to be overcome soon since progress consists in universalization of free wage labor conditions over the entire globe (Werlhof 1984).

In this context, "housewife-ization" (Hausfrauisierung, see Mies, Bennholdt-Thomsen, and Werlhof 1988) of women subsequent to witch hunts shows, for the first time, how "international" conditions reappear on a "national" level or, to put it differently, how already in the initial stage of the world system the same things occur in microeconomics as in macroeconomics. It is exactly this "de-geographization" of conditions which generally characterizes the present "globalization." Compared to the historical international division of labor, globalization means that the North-South difference disappears, but not to make room for supposedly "civilized" conditions everywhere. On the contrary, it disappears geographically, but survives and prospers as a principle; as such it is celebrates its universal "globalization." Now it can roam anywhere, disconnected from continents or countries. Globalization, therefore, does not mean universalization of wage labor and the abolishing slavery and unpaid labor-such as housework. On the contrary, it means global extension of colonial conditions, namely slavery and unpaid labor or, to put it differently, it is the "housewife-ization," including men's labor, all over the world, and for one reason only: to lower labor costs and to increase profits.

The new political economy announced by the MAI rests on the same foundations laid during colonial times, a fact rarely recognized. With the new expansion of "permanent" processes of original accumulation, the principally, and not only initially, violent character of our world-economy is again coming forth with increased force in the centers, too. Throughout history, immediate producers have never parted voluntarily with their culture, their means of production, their labor power, let alone control over their own bodies. Such violence of expropriation, was called by Karl Marx primitive accumulation's "secret," one shared as well by the globalized economy of today. It was not by chance that the MAI was conceived under a shroud of secrecy in a Parisian cellar.
THE MAI-"ECONOMY" ORः WHERE (UN-)FREEDOM IS LIMITLESS "INVESTOR" AND "INVESTMENT" IS THE ONE AND ONLY STANDARD OF CIVIL ACTION

"Investor" and "investment" are the fundamental concepts in the MAI (Werlhof 1998). The document works to defend their limitless freedom, their absolute protection and their 100 percent security: "safer investment." In reading the relevant passages, one does not immediately suspect anything bad, so long as one does not know the scope of the definition of investment and the extent to which investment activities are considered to be an almost absolute standard for all social life. The MAI defines investment as "every kind of asset owned or controlled, directly or indirectly, by an investor." Such an investment need not necessarily have anything to do with job creation. It does not refer to useful activities supplying the needs of a population, nor does it refer to the protection of resources or to any of the things the average person may have in mind when thinking of investment. In the MAI, "investment" is everything done by an investor, focussed simply on the increase of the investor's property and his control over resources. It does not matter whether he speculates or deals in drugs, arms, women or money laundering; whether he penetrates or monopolizes existing markets or creates new markets under his control; whether he exploits local mineral resources and gets hold of the land to build up new agricultural industries; or whether he takes for himself a patent out of local "intellectual property," the so-called TRIPS, (Trade Related Intellectual Property Rights) (Shiva 1995). The MAI seeks to give the investor limitless access to everything everywhere, including the so-called "virtual" spheres. The investor's main interest seems to be in property, namely the acquisition of available opportunities for profit maximization. In this sense the Canadians, for example, have, after four years of NAFTA (North American Free Trade Association, called the "little MAI"), learned that investment activities consist mainly of the purchase of, or elimination of other business companies followed by cost-cutting dismissal of employees (Clarke and Barlow 1997). Promises from NAFTA-advocates to create 200,000 jobs remain unkept while 400,000 jobs have been eliminated in the U. S. A. alone (Wallach and Naiman 1998).

The market structure reveals itself as power structure: monopolies, oligopolies and cartels dominate. "Mega-enterprises" destroy competition (Noé 1998). National anti-trust offices do not object to "companies getting 
bigger and bigger... since the others are doing the same" (ibid.). "We are in danger of putting ourselves at the mercy of a steadily decreasing number of private power centers and their globally acting managers who call themselves, full of self-confidence, 'Global Players"' (Kartte, former president of the cartels office, quoted in Noé, ibid.). Such "looting associations" (Noé) are seldom criticized these days, even though Adam Smith, founder of modern economic liberalism, explicitly warned of the formation of monopolies. For Smith, free trade was only possible if enterprises were owned locally, with their roots in the communities (1976). To an increasing extent this is no longer the case. The investor the MAI has in mind must rather be compared to the "absentee landlord," with investment looking more like a colonial "enclave," run anonymously like an alien property whose owner cannot be reached, sometimes disappearing overnight together with his "business," a practice made possible by "capital-flexibility" under present technological circumstances. In any case, such owners aren't affected by damages done locally, and as is known from experience, in case of doubt feel no responsibility for such damages (e.g. Seveso in Italy and Bhopal in India; Korten 1996). Because the principles of "permanent" original accumulation have always been clearest in agriculture, it is no coincidence that a certain phase in the history of the agrarian sector resembles the actions of the MAI-investor. This phenomenon is still mistaken for "feudalism" or Third World "traditionalism," whereas, in reality, these processes are the most profitable of the modern economy (Werlhof 1985; Werlhof and Neuhoff 1982).

This "investment" has already spelled death for local business enterprises all over the world, a process which, with the advent of the MAI, will only increase in the future, paradoxically, threatening "free enterprise." Entrepreneurs and business people expecting protection from the MAI as investors do not seem to understand this process; but why should big international corporations let smaller investors have their profits? The crux of the matter is that the investor sees himself as a (legal) person or institution characterized by one and only one interest, namely maximizing profits with no restraints. Thus profits will be exported rather than left in their country of origin when advantageous (Engels et al. 1998). Such "de-regulation" and "debureaucratization" of investment activities are considered to be particularly positive aspects of the MAI. Therefore, "the temptation for business companies" is increasingly "to become so gigantic that they present themselves as duchies for strategic market arrangements. When these arrangements are successful...competition is dictated by capitalist dukes and prince electors and takes place at the expense of the many nationally and regionally limited, so-called middle-class producers and services that look for credits." (C. Noé, op.cit.; "capitalist" added by C. v. W.) At present the 500 biggest companies control 80 percent of the world's investment activities.

The investor's interests are not only given highest economic priority but top social priority as well. "The investors' gains are the highest human value, everything else is of second order." (President of United Technologies, Gray, according to Chomsky 1995, p. 18). The protection of this species is, therefore, seen as "free trade" (ibid.) and not as protectionism, which, with respect to the rest of the market participants, is ridiculed as anachronistic. "Investment protection," within the MAI, does not mean protection of labor, the environment and nature, or human rights and the vital interests of the people (B. Mark-Ungericht 1998); it stands exclusively for the protection of the investor-monoculture. The protection of non-investors is considered a restriction of investor freedom.

Present troubles of capital valorization-the result primarily of the enormous increase of no longer "productively" covered finance capital and oversized profit expectations - are apparently so deep (Third World Resurgence 1998) that at a time when "the ecological limits of growth" push people to search for a "sustainable," even "subsistence-oriented" economy (Bennholdt-Thomsen and Mies 1997), the MAI would establish a radically opposite approach as the universal model and world constitution. With globalization, the race for the last resources of the globe has entered its final ruthless phase.

Globalization is not the fulfillment of the illusions of progress. On the contrary, it is the rapid and brutal disposal of the social advances made from the beginning of the industrial revolution until now. There are already eighteen million people unemployed in Europe, child labor amounts to one and a half million, and in England the "state of labor conditions" and "wage differences" mimic the figures of 1886 (Halimi). It seems that MAI provisions for investment can principally, and to a large extent, do without free wage labor. The key examples of this are the "free production zones," "world market factories" or "maquiladoras" of the South, where chips, electronics, and textiles are produced using a cheap, female labor force under conditions of forced 
labor (Mies 1986; Gabriel 1998). This colonial treatment of labor is spreading right at the time of a new technological development, or a so-called third industrial revolution which makes such colonization possible. The new technologies of computerization make it possible to drastically reduce labor — with reductions as high as $80 \%$ (Martin \& Schumann 1996) - and to use the cheapest form of untrained labor. High tech combines with low wage; a new form of slavery-home worker-appears in a high tech outfit. "Real" subsumption of labor under capital, in the sense of free wage labor, is being replaced by "marginal" subsumption of labor with marginal remuneration (Bennholdt-Thomsen 1980), labor "un-free" insofar as it no longer faces capital as a "free" and "equal" contractual partner. Critics of modern technologies are dismissed as anachronistic "Luddites" (Noble 1985; Ned Ludd from Nottingham, England, was the first to attack machine production and automation in the early decades of the $19^{\text {th }}$ century). Apparently technology and progress are still happily accepted although they have broken all their promises. Thus, for instance, "the end of labor" must be understood as the end of the wage.

It is therefore not surprising to see what in the MAI is called as "most-favored nation-principle", "non-discrimination," and "equal treatment" of investors and investments. Nothing must stand in the way of investor and investment, no matter what their objectives might be. It must be codified that those unequal competitors, namely corporations and smaller investors, are globally considered to be "equal." They are given the globally most favorable conditions, which is nothing but systematic "positive discrimination" for the great and the multiplication of their competitive and power advantages. The same result will be achieved by the fact that under certain sections of the MAI, certain branches, business firms, areas or regions will no longer be publicly supported or subsidized because the equal treatment or non-discrimination clause implies that any other investor has the same right to the support. Since, of course, the means for such "limitless" support are not available, the support mechanism as such breaks down and the survival chances of those who had been supported earlier will also be reduced to zero. The end result will be the abolition of welfare state elements such as health provisions, pensions and education.

Within such a political economy of monopoly-capital, which with the MAI would have only rights and neither duties nor responsibilities, there can no longer be any talk of the best possible provision of people and households in the "market economy". The "Fordist" model of paying wages that enable the workers to afford a Ford (Hirsch, Roth) is no longer necessary within a globalized economy because the markets are, from a global perspective, always big enough to absorb any production (Martin and Schumann 1996), at least so long as there is no depression. Therefore, the trade union's strategy of "re-distribution" will, on the whole, have no great chance of success. This strategy did not question the conditions of production as such (so-called investment) anyway, and was thus prepared to accept looting and exploitation.

THE MAI-POLITICS OR: THE WORLD AS COLONY OF CORPORATIONS. SO-CALLED "EXPROPRIATION" AS THE ONE AND ONLY STANDARD OF POLITICAL ACTION

The MAI economy can only serve "investors" if it is supported by policies that correspond to permanent "primitive accumulation." If primitive accumulation is understood as creating the prerequisites for "accumulation proper" by concentrating the relevant means of production in the hands of those who, on this basis, are able to accumulate, then, especially today, it becomes obvious why this process has not come to a historical conclusion, as Marx believed. On the contrary, particularly under the MAI, politics is clearly defined in such a way that "primitive" accumulation is carried out on a comprehensive, global scale under modern conditions. Such politics and policies enforce severe re-distribution from bottom to top, in all areas of the economy and by all means, violence and military intervention not excluded (Europäisches Parlament 1996). This political process, which is also part of the prerequisites of so-called globalization in general, has to be expected, particularly under the MAI-regime:

- Separation of small, medium-sized and even larger firms or investors from their capital; an increasing number of firms collapsing, "unfree" enterprise (for instance, new forms of sub-enterprises), credit-induced "contractual" production, new quasi self-employed people such as home-workers, "alternative" businesses, a general trend towards a "lumpenbourgeoisie" (Frank 1968; Bennholdt-Thomsen 1988; Werlhof 1983).

- Renewed separation of farmers from their land; expulsion of farmers, abolition of agrarian reform laws (as presently in Mexico); coercive 
introduction of genetic and new reproduction technologies in agriculture, animal raising and plant growing; patenting of life forms; robbery of "intellectual property" of indigenous producers (Shiva 1998; Mies and Shiva 1993; Forum on Land, Food Security and Agriculture 1998).

- The technological separation of women from their bodies: coercive introduction of genetic and reproductive technologies for eugenic purposes, generally further reduction of women's control over their own bodies and continued experiments to break women's child-bearing "monopoly" (Bergmann 1992; Werlhof 1997a).

- Separation of workers-men and women-from their work place, their wages, and their labor power as such: "wageless commodity production," generally precarious employment conditions such as parttime work, 620-DeutscheMarks-jobs, "flexibilization" of work; work paid below the subsistence level; exploitation of unpaid work according to the model of a housewife's work in the form of expanding "house-wifeization" of employment conditions; general marginalization of labor force or "lumpenproletarianization" and general reduction of people to mere and simply potentially usable "raw material" which, according to demand, can be utilized or destroyed (Anders 1980; Bennholdt-Thomsen 1979).

- Separation of the public hand (local communities, states, central governments) from its property; "privatization" in favor of private monopolies. Sale of land, buildings, public enterprises, community property and the "commons" (Clarke 1997).

"Expropriation" is, next to "investment," the central category of the MAI and it is equally widely understood as well as equally perverted. "Expropriation" in the MAI is a collective term for circumstances that are to be avoided because they are considered detrimental or obstructive to investment activities. The term is not only used in the classical sense of nationalization or socialization or even "socialist expropriation." According to the MAI, the term of expropriation even includes "indirect" ("creeping") expropriation which is already the case when expected profits do not occur or occur only partly, for instance, on account of the validity of existing laws, common law, or because of disturbances. Therefore, the MAI provides that all laws and regulations which at some time and some place could hinder the investor's freedom, and would thus not conform to the MAI, would have to be abolished retroactively ("roll-back" clause). Of course, no such new laws and regulations must be introduced for the 20 year duration of the contract ("stand still" clause), which makes any policies of non-conformity with the MAI impossible. Finally, any investor who feels hindered can at any time resort to the MAI dispute settlement mechanism to enforce his interests before an international court of arbitration which puts itself out of reach of any democratic control. The investor may sue for damages against any local community, country, government or other investor because of "expropriation," meaning in his eyes he is hindered by the defendant in realizing his freedom of investment. As we know, the MAI arbitration tribunal is constructed in such a way that it will, in any case, support the "requesting" investor, for otherwise he could resort to the relevant local or national courts. Furthermore, there have been precedents in Canada and Mexico in which it has been argued that the investors' rights have precedence over potential health hazards to the population affected (for example, the case of the U.S. Ethyl Corporation in Canada, in which the company has won against the Canadian state; Toronto Star 1998).

As for the MAI's treatment of the term of expropriation, the following consequences must be mentioned: "Expropriation" does not really refer to the threat of expropriation of the investor, but to the investor threatening others with expropriation. In fact, non-investors as well as smaller and medium-sized investors are expropriated in favor of large investors. This is the classical case of robbery in the sense of primitive accumulation which, however, with the MAI, becomes a legal procedure if not the legal standard. The MAI thus affirms and legalizes a tendency that so far has grown ruthlessly, but has always been treated ambivalently by the judiciary. Those who attempt to fight the sacrifice of their health, nutrition, welfare and vital interests must risk classification as potential criminals under the MAI.

The MAI is, in the eyes of its advocates, not only a "political" contract but almost the materialization of a "natural law." From this angle, the MAI is a long "necessary" act to enable globally pure capital utilization liberated from any natural and social restrictions. It is the "level playing field cleared of all obstacles and bumps," the "operating theatre," the purified battlefield. The MAI defines anew what is "nature" and what is "culture." In addition to women, peasants, and colonized people, everybody else is defined out of cul- 
ture and back into "nature," apart from a tiny minority who exclusively claim the achievements of culture and "civilization" for themselves. Since "nature" as such is seen as having no "value," the labor and lives of "naturalized" people seem to have no value either (Werlhof 1988).

The MAI would be the basis of a new political world order or world constitution and a new nation-state: the MAI-state. It defines the fundamental conditions of legal and political actions - the "mono-pol-itics"-for the next twenty years. With the MAI, governments on all levels are not simply divested of their sovereignty, as is often complained (Clarke and Barlow 1997; 1998). By signing the agreement they are trying to rob the people of their sovereignty or to "separate" them from their sovereignty, which, according to the idea of democratic constitutions, is impossible. At the same time signatory governments lose much of their sovereignty by allowing investors not only a status equal to the standing of the nation-state but of even greater power and higher order: in dispute settlements with private investors they can be the losers. Governments also reduce their economic power by allowing the privatization of public property that is already being sold to private investors not only to fill up the state treasury or public purse but also to partly enrich corporations. With the MAI, governments even allow the order of competition and their legal cartel regulations or antitrust laws to be sacrificed to private monopolies by considering the political order problem of monopolies (or oligopolies) only in the area of public or state monopolies and not as referring to private monopolies. According to the MAI only state and not private monopolies have a negative connotation.

The state shall not, however, be abolished. It will always have to take care of the investors' primitive accumulation (as well as its own). In this sense, the state turns into the "pimp" for its own population and for more "resources," which it can offer to investors at globally most favorable conditions. "Poverty is the criterion for securing the location of investment" (Zumach 1996). Since force and violence (must) dominate at that level, the state progressively turns into a police state, a military state ( $\mathrm{s}$. the Tindemans-Report of the European Parliament 1966). It will (have to) "educate" (Halimi) its population as far as possible to identify with the investors' interests and to internalize these interests to the extent that civil disturbances, which might get the state into the trouble of being sued for damages by an investor, are repressed even preventively. In case this education-which could form the basis of a new educational system in MAI-states-does not do its job, the MAI does not restrict the state in establishing law and order. On the contrary, the areas of "inner security" are the only areas that are explicitly excluded by the MAI.

The "MAI-revolution," therefore, implies that the modern nation-state of the center, turns into a ("semi-)peripheral" colonial state to guarantee that inside it primitive accumulation can take place on a large scale, whereas corporations turn into "nation-states" of central importance, forming the top of the new global pyramid of the "capitalist world system." The MAI proves that capitalism and democracy appear and stay together only so long as the colonial regime or primitive accumulation has not yet been established everywhere for everybody. It also proves that its starting point is a contradiction between "investments" and human rights or vital interests of the population (cf. the Harvard study quoted by Drake et al. 1998). The Zapatista movement in Mexico, which started with NAFTA (Werlhof 1997b), calls this development a "New World War" and speaks of a "war against all peoples, against human beings, culture, history... Neo-liberalism (is) a process of renewed conquest of the land...the conquerors are the same as 500 years ago...they tell us that we are an obstacle, we are not only dispensable, we are an obstacle to progress" (Marcos 1995). Since then, the Mexican government is said to have been asked by the Chase Manhattan Bank in the U.S. A. to liquidate the Zapatista movement by military force, since it is a threat not to the state as such but to the investors' belief in political stability in Mexico (Pérez 1998).

With the MAI a similar development may occur in North America and Europe. The term "permanent" primitive accumulation is an analytical instrument to explain the political consequences of the MAI and to understand its logic of the "necessity" of permanent political violence. In this kind of "expanded" primitive accumulation the state is given a new order in which there is a tendency to abolish the traditional division of powers and in which its power no longer comes "from the people" but is rather systematically turned against the people. This tendency is also growing in the "centers." Real political power is, with the MAI, "legally" taken from the people and given to big corporations, thus creating a new "corporatism," a new form of co-operation between state and capital that particularly characterizes modern dictatorship (Boulboullé and Schuster). 


\section{CONCLUSION}

The discussions, disputes and struggles which we may expect for the near future will, therefore, not only concern the "distribution of the loot" from the process of (primitive) accumulation, nor will it be about extended "participation" in a changing political order. It will primarily have to deal with the abolition of "permanent" primitive accumulation and as such it will also deal with the secret basis of the entire process of accumulation: In the final analysis we will no longer be concerned with participation in capitalist "productive" property which has for quite some time now turned out to be "destructive" property. This is why property and "prosperity" exist not for more and more, but for fewer and fewer people. A world-"economy" plundering the planet cannot last forever. Therefore, we will have to desert the "TINA"-There Is No Alternative- - syndrome" (Shiva 1993) and re-conquer the true means (of subsistence) which we need for our daily lives.

The universal quasi-religious belief in technological progress, economic "growth," corporate "rationality," and its outcome money, will increasingly contradict reality (Binswanger 1998). "Greed does not feed" (Prakash and Mourin 1998). The global economic crisis can no longer be "triggered" by "financial warfare" (Chossudovsky 1998). Finally, the pre-condition of western confidence in the "capitalist world-system," the old patriarchal utopia of being able to replace the "bad world" with a man-made "brave new world" will be recognized as lethal fraud. Therefore, the main problem - with and without the MAI-will consist in finding again a "real" economy, an economy not organized around profit, competition and the colonization of people and nature. At the end of progress we will have to approach the end of violence and recreate a culture built on co-operation and co-existence (Wallerstein 1991). For that purpose we need what capitalism and patriarchy have tried to "separate" us from: a "dissident" mind based on the radical acceptance of life.

\section{REFERENCES}

Anders, Günther (1980). Die Antiquiertheit des Menschen, II. Über die Zerstörung des Lebens im Zeitalter der 3. Industriellen Revolution. München.

Bennholdt-Thomsen, Veronika (1979)."Marginalität in Lateinamerika-Eine Theoriekritik," Lateinamerika, Analysen und Berichte 3, Berlin, 45-85.
Bennholdt-Thomsen, Veronika (1980)."Towards a Class Analysis of Agrarian Sectors: Mexiko," Latin American Perspectives, Vol. VII, No. 4, 100-114.

Bennholdt-Thomsen, Veronika (1988). "Investment in the Poor: an Analysis of World Bank Policy," Mies, Maria; Bennholdt-Thomsen, Veronika; and von Werlhof, Claudia, Women, the Last Colony, London, 51-63.

Bennholdt-Thomsen, Veronika and Maria Mies (1997). Eine Kub für Hillary. Die Subsistenzperspektive. München.

Bergmann, Anna (1992). Die verbütete Sexualität. Die Anfänge der modernen Geburtenkontrolle. Hamburg.

Binswanger, Hans-Christoph (1998). Die Glaubensgemeinschaft der Ökonomen. Essays zur Kultur der Wirtschaft. München.

Boulboullé, Carla and H.W. Schuster (1998)."Mit den Verträgen von Maastricht und Amsterdam und der Einheitswährung 'EURO' bahnen die Regierungen der EU dem MAI-Vertrag den Weg," Soziale Politik E Demokratie, Sondernummer zum MAI-Vertrag, April 21.

Clarke, Tony and Maude Barlow (1998). The MAI and the Threat to American Freedom. Toronto.

Chomsky, Noam (1995). Wirtschaft und Gewalt. Vom Kolonialismis zur neuen Weltordnung. München; English ed. (1993). Year 501: The Conquest Continues. Boston.

Chossudovsky, Michel (1998). "Financial Warfare triggers Global Economic Crisis," Third World Resurgence, No. 98, October (Penang), 5-10.

Clarke, Tony (1997). Silent Coup. Confronting the Big Business Takeover of Canada. Toronto.

Clarke, Tony and Maude Barlow (1997). MAI: The Multilateral Agreement on Investment and the Threat to Canadian Sovereignty. Toronto.

Drake, Elizabeth, Laura Benygar, and Michael Ewing et al. (1998). The Multilateral Agreement on Investment: A Step backward in International Human Rights. Harvard Law School, Human Rights Clinical Project Program/The Robert F. Kennedy Memorial Center for Human Rights, Cambridge.

Engels, Rainer, Jens Martens, Peter Wahl et al. (1998). "Alles neu macht das MAI. Das Multilaterale Investitionsabkommen. Informationen, Hintergründe, Kritik," (WEED/Germanwatch), Bonn (March).

Europäisches Parlament (1996)."Entwurf eines Berichts über eine Sicherheits- und Verteidigungspolitik für die Europäische Union,” Ausschuß für Auswärtige Angelegenheiten, Sicherheit und Verteidigungspolitik, Berichterstatter: Leo Tindemans, Brüssel, June 11.

Forum on Land, Food Security and Agriculture (1998). "Statement, International Conference on 'Confronting Globalization, Asserting our Right to Food," Kuala Lumpur (Malaysia), November 11-12.

Frank, André Gunder (1968). Kapitalismus und Unterentwicklung in Lateinamerika, Frankfurt am Main.

Frank, André Gunder (1976). World Accumulation, 1492-1789. New York.

Gabriel, Leo (1998). Die globale Vereinnahmung und der Widerstand in Lateinamerika. Wien.

Halimi, Serge (1996). "Schlank und flexibel hinein in die Armut," Le Monde Diplomatique, (July) 
Hirsch, Joachim and R. Roth (1986). Das neue Gesicht des Kapitalismus. Vom Fordismus zum Postfordismus. Hamburg.

Khor, Martin (1998). “Die Folgen für den Süden,” Mies and Werlhof (eds., 1998); Lizenz zum Plündern. Das Multilaterale Abkommen über Investitionen-MAI-

Globalisierung der Konzernherrschaft_ - und was wir dagegen tun können, Hamburg, 79-91.

Kommittee Widerstand gegen das MAI (1998), "MAI, der Gipfel der Globalisierung," Reader zum Kongreß, Bonn.

Korten, David (1996). When Corporations Rule the World. Westhardford.

Korten, David (1998). Globalizing Civil Society. Reclaiming our Right to Power. New York.

Luxemburg, Rosa (1971, 1st ed. 1923). The Accumulation of Capital. London.

Mark-Ungericht, Bernhard (1998). Der Staat, die Politik und der Widerstand gegen das MAI (manuscript). Graz.

Martin, Hans-Peter and Hans Schumann (1996). Die Globalisierungsfalle. Reinbek.

Marx, Karl (1974, 1st ed. 1867). “Die sogenannte ursprüngliche Akkumulation,” Marx, Karl/Engels, Friedrich: Werke. Vol. 23, 741-791, Berlin.

Mies, Maria (1986). Patriarchy and Accumulation on a World Scale. Women in the International Division of Labor. London.

Mies, Maria, Veronika Bennholdt-Thomsen, and Claudia von Werlhof (1988). Women, the Last Colony. London.

Mies, Maria and Vandana Shiva (1993). Ecofeminism. London.

Mies, Maria and Claudia von Werlhof (eds.) (1998). Lizenz zum Plündern. Das Multilaterale Abkommen über Investitionen-MAI-Globalisierung der Konzernherrschaft—und was wir dagegen tun können. Hamburg.

Noble, David (1985). Automation: Progress without People. San Pedro, California.

Noé, Claus (1998): Warten auf das Weltkartellamt, in: Die Zeit, No. 11, May 3.

OECD (Organization of Economic Co-operation and Development) $(1997,1998)$. The Multilateral Agreement on Investment, the MAI Negotiating Text. Directorate for Financial, Fiscal and Enterprise Affairs, Paris.

Prakash, Suria and Jennifer Mourin (1998). "Hey TNCs! You can't feed the world on greed," Report from PANasia Pacific, Listserver of Diverse Women for Diversity, New Delhi.

Review (1980). Vol. IV No. 1 (summer).

Review (1983). Vol. VII, No. 2 (fall),"The Household and the Large-Scale-Agricultural Unit."

Shiva, Vandana (1993). Monocultures of the Mind. Penang.

Shiva, Vandana (1995). Trading our Lives away. An Ecological and Gender Analysis of "Free Trade" and WTO. Penang/New Delhi.

Shiva, Vandana (1998). Listserver of Diverse Women for Diversity, various numbers, New Delhi.

Smith, Adam (1776). An Enquiry into the Nature and Causes of the Wealth of Nations. London.

Smith, Joan, Immanuel Wallerstein, and Hans-Dieter Evers (1984). Households and the World-Economy. Beverly Hills: Sage.
TAZ (Die Tageszeitung) (1998): October 15.

Third World Resurgence (1998). (Penang), October.

Toronto Star (1998). July 21.

Wallach, Lori and Robert Naiman (1998). "NAFTA. Four and a half Years later," The Ecologist, Vol. 28, No. 3, May/June.

Wallerstein, Immanuel (1974a). The Modern World-System I. New York: Academic Press

Wallerstein, Immanuel (1974b)."The Rise and Future Demise of the World Capitalist System: Concepts for Comparative Analysis," Comparative Studies in Society and History, 16 (4), 387-415.

Wallerstein, Immanuel (1980). The Modern World-System II: Mercantilism and the Consolidation of the European World-Economy, 1600-1750. San Diego/London: Academic Press.

Wallerstein, Immanuel (1985). Preface, in: Werlhof, Claudia von, Wenn die Bauern wieder kommen. Frauen, Arbeit und Agrobusiness in Venezuela. Bremen, 16-19.

Wallerstein, Immanuel (1989). The Modern World-System III: The Second Era of Great Expansion of the Capitalist World-Economy, 1730-1840. San Diego/London: Academic Press.

Wallerstein, Immanuel (1991). Unthinking Social Science: The Limits of Nineteenth-Century Paradigms. Cambridge: Polity.

Werlhof, Claudia von (1978)."Frauenarbeit: Der 'blinde Fleck' in der Kritik der Politischen Ökonomie," Beiträge zur feministischen Therorie und Praxis, I: Erste Orientierungen, Köln (English ed.: "Women's work: The blind spot in the critique of political economy," Mies, Maria, Veronika Bennholdt-Thomsen, Claudia von Werlhof (1988). Women, the Last Colony. London, 13-26)

Werlhof, Claudia von (1983)."Production Relations without Wage Labor and Labor Division by Sex," Review, VII, 2 (Fall), 315-359.

Werlhof, Claudia von (1984)."The Proletarian is dead; long live the Housewife?," Smith, Joan, Immanuel Wallerstein, Hans-Dieter Evers (eds.), Households and the WorldEconomy, Beverly Hills/London/New Delhi, 131-147.

Werlhof, Claudia von (1985). Wenn die Bauern wieder kommen. Frauen, Arbeit und Agrobusiness in Venezuela, Bremen.

Werlhof, Claudia von (1985)."Why Peasants and Housewives do not Disappear in the Capitalist World-System," working paper No. 68, Sociology of Development Research Center, University of Bielefeld, Bielefeld.

Werlhof, Claudia von (1991)."Teile und Herrsche. Warum Bauern und Hausfrauen im kapitalistischen Weltsystem nicht verschwinden," Was haben die Hühner mit dem Dollar zu tun? Frauen und Ökonomie, München, 83-113.

Werlhof, Claudia von (1988)."On the Concept of Nature and Society in Capitalism," Mies, Maria, Veronika Bennholdt-Thomsen, and Claudia von Werlhof, Women, the Last Colony, London, 96-112.

Werlhof, Claudia von (1997a). "Schöpfung aus Zerstörung? Die Gentechnik als moderne Alchemie und ihre ethisch-religiöse Rechtfertigung” Baier, Wilhelm (ed.), Genetik. Einführung und Kontroverse, Graz, 79-115. 
Werlhof, Claudia von (1997b). “Upheaval from the Depth. The 'Zapatistas,' the Indigenous Civilisation, the Question of Matriarchy and the West," International Journal of Comparative Sociology, XXXVIII, 1-2, June,106-130.

Werlhof, Claudia von (1998).“MAInopoly: Aus Spiel wird Ernst," Mies, Maria and Claudia von Werlhof (eds.): Lizenz zum Plündern. Das Multilaterale Abkommen über Investitionen-MAI-Globalisierung der Konzernherrschaft—und was wir dagegen tun können, Hamburg, 131-176.

Werlhof, Claudia von and Hanns-Peter Neuhoff (1982)."The Combination of Different Production Relations on the Basis of Non-Proletarianization: Agrarian Production in Yaracuy, Venezuela," Latin American Perspectives, 34 (summer), Vol. IX, No. 3, 79-103.

Zumach, Andreas (1996). “Armut ist das Kriterium, das den Standort sichert," TAZ (Die Tageszeitung), No. 5099, Berlin, December 9. 